\title{
Streptomyces osmaniensis sp. nov., isolated from soil
}

\author{
T. V. K. Reddy, ${ }^{1}$ Shaik Mahmood, ${ }^{1}$ M. Mohammed Idris ${ }^{2}$ \\ and Slawomir Ciesielski ${ }^{3}$
}

Correspondence

Shaik Mahmood

skmahmood@osmania.ac.in

T. V. K. Reddy

reddykishoretv@gmail.com

\author{
${ }^{1}$ Microbiology Lab, Department of Botany, University College of Science, Osmania University, \\ Hyderabad 500 007, India \\ ${ }^{2}$ Centre for Cellular and Molecular Biology, Uppal Road, Hyderabad 500 007, India \\ ${ }^{3}$ Department of Environmental Biotechnology, University of Warmia and Mazury in Olsztyn, ul. \\ Sloneczna 45G, Olsztyn, Poland
}

The family Streptomycetaceae, which comprises the genera Streptomyces, Kitasatospora and Streptacidiphilus, was proposed by Waksman \& Henrici (1943) and its description was emended by Kim et al. (2003). At the time of writing, the genus Streptomyces comprises over 550 recognized species (Euzéby, 2009). Streptomyces species are aerobic actinomycetes and most of them are able to form an extensively branched substrate mycelium and aerial hyphae that typically differentiate into chains of spores. Members of the genus have LL-diaminopimelic acid in the cell-wall peptidoglycan, but no characteristic sugars (wall chemotype I sensu Lechevalier \& Lechevalier, 1970) and possess DNA rich in G+C (Williams et al., 1983; Manfio et al., 1995). The streptomycetes, producers of more than half of the 10000 documented bioactive compounds (for example antibiotics, enzymes, inhibitors and pharmacologically active agents), have offered over 50 years of interest to industry and academia (Anderson \& Wellington, 2001; Berdy, 2005). In the course of a screening programme for antibiotics, a novel strain, OU$63^{\mathrm{T}}$, was isolated from a garden soil sample collected on Osmania University campus, Hyderabad, India, and was

The GenBank/EMBL/DDBJ accession number for the $16 \mathrm{~S}$ rRNA gene sequence of strain OU-63 ${ }^{\top}$ is FJ613126.

A table detailing the growth and cultural characteristics of strain OU-63 on various media is available as supplementary material with the online version of this paper. provisionally assigned to the genus Streptomyces by using chemotaxonomic and morphological properties. A polyphasic taxonomic investigation based on a combination of phenotypic and genotypic characteristics revealed that strain OU $-63^{\mathrm{T}}$ represents a novel species of the genus Streptomyces.

Strain OU-63 ${ }^{\mathrm{T}}$ was isolated by using a modification of the protocol developed by Atalan et al. (2000) on actinomycetes isolation agar (Himedia) supplemented with cycloheximide $\left(50 \mu \mathrm{g} \mathrm{ml}^{-1}\right)$ and nystatin $\left(25 \mu \mathrm{g} \mathrm{ml}^{-1}\right)$. The agar was seeded with the soil suspension and incubated for 14 days at $28{ }^{\circ} \mathrm{C}$ (Olson, 1968). The new isolate was maintained on oatmeal agar slants [International Streptomyces Project (ISP) medium 3; Shirling \& Gottlieb, 1966] at $4{ }^{\circ} \mathrm{C}$ and as glycerol suspensions $(20 \%, \mathrm{v} / \mathrm{v})$ at $-20{ }^{\circ} \mathrm{C}$.

The morphological characteristics of strain OU- $63^{\mathrm{T}}$ were examined by light and scanning electron microscopy of 14day-old cultures on ISP medium 3 (Williams \& Davies, 1967). The coverslip technique (Zhou et al., 1998; Kawato \& Shinobu, 1959) was used to observe hyphae and spore chains by light microscopy. Spore-chain morphology and sporesurface ornamentation were studied by examining goldcoated, dehydrated specimens with a scanning electron microscope (JSM 5600; JEOL). Growth and cultural characteristics were observed on various media after incubation at $28{ }^{\circ} \mathrm{C}$ for 14 days. A range of physiological 
and biochemical properties was tested as described by Shirling \& Gottlieb (1966) and Williams et al. (1983).

The isomer of diaminopimelic acid and whole-cell sugars were analysed following the procedures developed by Hasegawa et al. (1983) and Lechevalier \& Lechevalier (1980). Menaquinones were extracted and purified according to Collins (1985) and were analysed by HPLC. Fatty acid analysis was performed by GC according to the transmethylation technique described by Lepage \& Roy (1984). The DNA G + C content of strain OU-63 ${ }^{\mathrm{T}}$ was determined by using the thermal denaturation method (Mandel \& Marmur, 1968).

Isolation of DNA was performed according to the method of Tripathi \& Rawal (1998). Amplification of the 16S rRNA gene of strain OU-63 $3^{\mathrm{T}}$ by PCR was carried out as described by Lane (1991). The amplified product was directly sequenced on a 3100 automatic DNA sequencer (Applied Biosystems). The 16S rRNA gene sequence of strain OU$63^{\mathrm{T}}$ was manually aligned with the corresponding sequences of representative Streptomyces species retrieved from the DDBJ, EMBL and GenBank databases. The program MEGA version 2.1 (Kumar et al., 2001) was used for both multiple alignment and phylogenetic analysis. Phylogenetic analyses were performed by using the neighbour-joining (Saitou \& Nei, 1987) and maximumparsimony (Fitch, 1971) methods. A phylogenetic tree was constructed with the neighbour-joining method from an evolutionary distance matrix generated according to the coefficient of Jukes \& Cantor (1969). The topologies of the phylogenetic trees were evaluated by bootstrap analysis (Felsenstein, 1985) with 1000 replicates.

The level of DNA-DNA relatedness between strain OU- $63^{\mathrm{T}}$ and Streptomyces chartreusis NBRC $12753^{\mathrm{T}}$ was determined by using the dot-blot hybridization method (Chung et al., 1999) and a simple fluorimetric method for estimation of DNA-DNA relatedness based on thermal denaturation temperatures (Gonzalez \& Saiz-Jimenez, 2005). Genomic DNA (200 and $400 \mathrm{ng}$ as homoduplex and heteroduplex DNA, respectively) was used for melting curve analysis in a $10-\mu \mathrm{l}$ reaction volume with a final $1 \times$ concentration of SYBR green. Analyses of the melting curves were performed by using initial denaturation for $10 \mathrm{~min}$ and renaturation for $5 \mathrm{~min}$, followed by heating from 20 to $90{ }^{\circ} \mathrm{C}\left(2{ }^{\circ} \mathrm{C} \min ^{-1}\right)$. Melting curves were plotted in triplicate. $\Delta T_{\mathrm{m}}$ values between homologous and hybrid DNA of $5{ }^{\circ} \mathrm{C}$ or higher were considered as indicative of different bacterial species.

The chemical and morphological properties of strain OU- $63^{\mathrm{T}}$ were consistent with its assignment to the genus Streptomyces (Williams et al., 1989; Manfio et al., 1995). The organism formed extensively branched substrate mycelium and aerial hyphae which carried spiny-surfaced cylindrical spores in spiral chains (Fig. 1). The cultural characteristics of strain OU-63 $3^{\mathrm{T}}$ on various standard media are given in Supplementary Table S1, available in IJSEM Online. The strain contained LL-diaminopimelic acid in the cell-wall

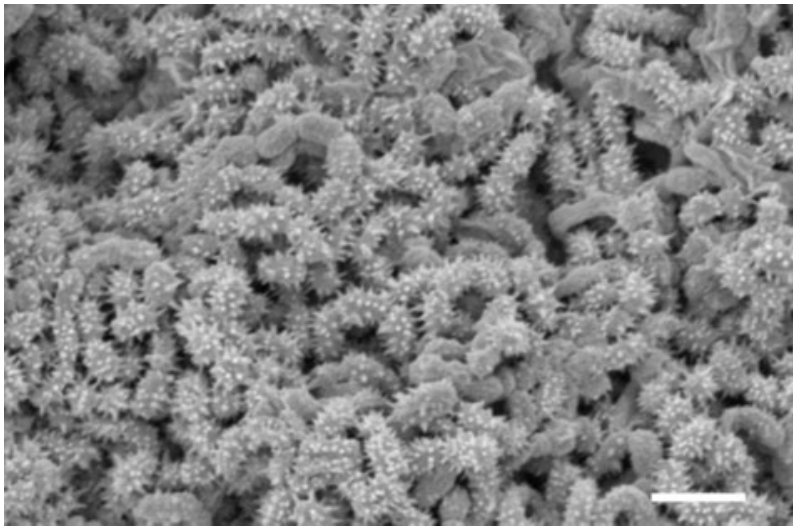

Fig. 1. Scanning electron micrograph of cells of strain OU-63 grown on oatmeal agar for 14 days at $28^{\circ} \mathrm{C}$. Bar, $2 \mu \mathrm{m}$.

peptidoglycan and no characteristic sugars (cell-wall chemotype I of Lechevalier \& Lechevalier, 1970). It contained MK-9 $\left(\mathrm{H}_{6}, \mathrm{H}_{8}\right.$ and $\left.\mathrm{H}_{4}\right)$ as the predominant isoprenologue. The predominant fatty acids were iso- $\mathrm{C}_{16: 0}(23 \%)$, iso- $\mathrm{C}_{15: 0}$ $(17 \%)$, iso- $\mathrm{C}_{17: 0}(13 \%)$, anteiso- $\mathrm{C}_{15: 0}(12 \%)$, anteiso- $\mathrm{C}_{17: 0}$ $(10 \%), \mathrm{C}_{16: 0}(7 \%)$ and iso- $\mathrm{C}_{14: 0}(5 \%)$, consistent with the fatty acid profiles obtained for recognized Streptomyces species. The $\mathrm{G}+\mathrm{C}$ content of the DNA of strain $\mathrm{OU}-63^{\mathrm{T}}$ was $71.6 \mathrm{~mol} \%$.

The partial 16S rRNA gene sequence (1418 nt) of strain OU- $63^{\mathrm{T}}$ was determined in this study. Primary analysis with sequences of representatives of the family Streptomycetaceae confirmed that strain OU-63 ${ }^{\mathrm{T}}$ was related closely to members of the genus Streptomyces. A neighbour-joining tree (Fig. 2) based on 16S rRNA gene sequences indicated that strain OU- $63^{\mathrm{T}}$ formed a tight cluster with Streptomyces chartreusis NBRC $12753^{\mathrm{T}}(98.6 \%$ sequence similarity), albeit with only moderate bootstrap support $(54 \%)$. The position of strain OU- $63^{\mathrm{T}}$ in the phylogenetic tree was unaffected by the choice of treemaking algorithm or outgroup strains used. Relatively high levels of $16 \mathrm{~S}$ rRNA gene sequence similarity were also found between strain OU-63 ${ }^{\mathrm{T}}$ and Streptomyces resistomycificus NBRC $12814^{\mathrm{T}}$ (98.1\%), 'Streptomyces argillaceus' JCM 4975 (98.1\%) and Streptomyces bungoensis NRRL B$24305(98.0 \%)$. Strain OU-63 ${ }^{\mathrm{T}}$ showed levels of $16 \mathrm{~S}$ rRNA gene sequence similarity lower than $98.0 \%$ to the type strains of other recognized Streptomyces species.

Strain OU-63 ${ }^{\mathrm{T}}$ could be distinguished from all of its close phylogenetic relatives based on a combination of phenotypic properties (Table 1). The level of DNA-DNA relatedness between strain OU-63 ${ }^{\mathrm{T}}$ and Streptomyces chartreusis NBRC $12753^{\mathrm{T}}$ was $25 \pm 1.73 \%$ (mean \pm SEM of three determinations), which is well below the $70 \%$ cut-off for recognition of genomic species (Wayne et al., 1987), thus suggesting that the strain should be considered as representing a separate species. DNA-DNA hybridization studies were not carried out between strain $\mathrm{OU}-63^{\mathrm{T}}$ and 


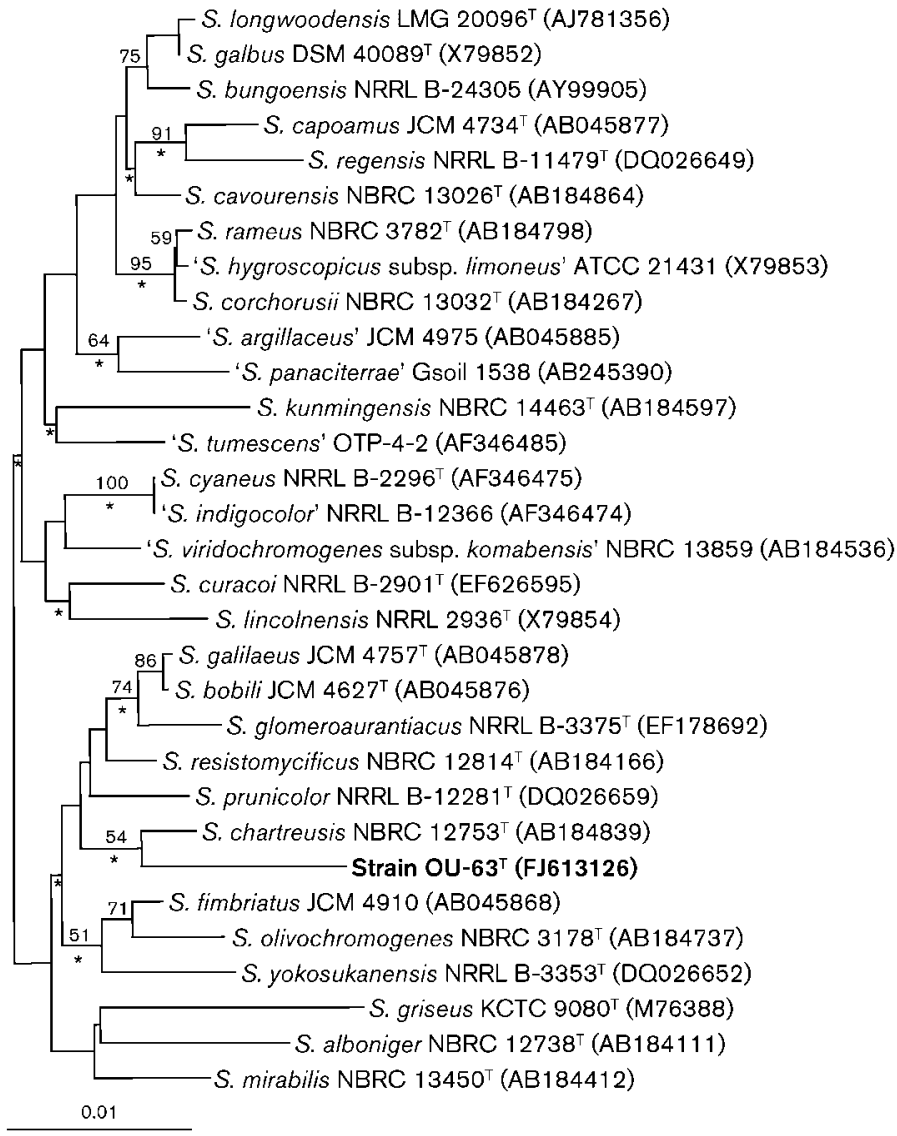

Fig. 2. Neighbour-joining phylogenetic tree showing the relationship between strain OU$63^{\top}$ and representative members of the genus Streptomyces based on 1401 unambiguously aligned nucleotides of 16S rRNA gene sequence. Numbers at nodes are bootstrap support percentages based on 1000 sampled datasets; only values $>50 \%$ are shown. Asterisks indicate the branches that were also found in the maximum-parsimony tree. Bar, 0.01 substitutions per nucleotide position.

Table 1. Differential characteristics between strain $\mathrm{OU}-63^{\top}$ and the type strains of related Streptomyces species

Strains: 1 , OU $-63^{\mathrm{T}}$; 2, S. chartreusis NBRC $12753^{\mathrm{T}}$; 3, S. resistomycificus NBRC $12814^{\mathrm{T}} ; 4$, S. prunicolor NRRL B-12281 ${ }^{\mathrm{T}}$. + , Positive;,- negative; ND, no data. Data for reference type strains were taken from Shirling \& Gottlieb $(1968,1972)$ and Williams et al. (1983).

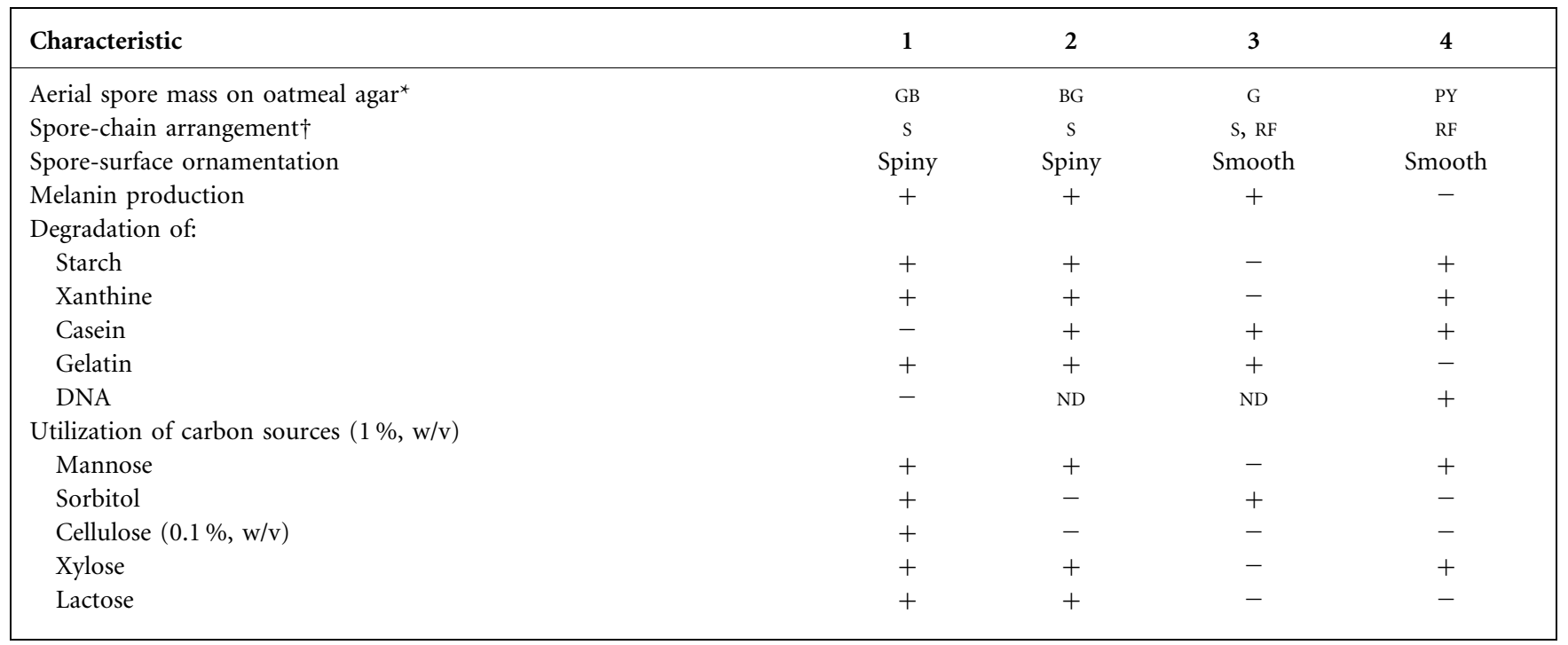

${ }^{*} \mathrm{BG}$, Bluish grey; G, grey; GB, greyish blue; PY, pale yellow.

$\dagger$ RF, Rectiflexibiles; s, spirales. 
other Streptomyces species, as pairwise 16S rRNA gene sequence similarities were low ( $\leqslant 98 \%$ ) (Sembiring et al., 2000; Kim \& Goodfellow, 2002; Manfio et al., 2003). The $\Delta T_{\mathrm{m}}$ value obtained from the thermal denaturation method between the homologous (Streptomyces chartreusis NBRC $12753^{\mathrm{T}}$ ) and hybrid (Streptomyces chartreusis NBRC $12753^{\mathrm{T}}$ and strain OU-63 ${ }^{\mathrm{T}}$ ) DNA was $7.5^{\circ} \mathrm{C}$. A $\Delta T_{\mathrm{m}}$ value of $5{ }^{\circ} \mathrm{C}$ or higher is considered to indicate a separate bacterial species (Wayne et al., 1987; Rosselló-Mora \& Amann, 2001). Based on the genotypic and phenotypic evidence, strain $\mathrm{OU}-63^{\mathrm{T}}$ is therefore considered to represent a novel species of the genus Streptomyces, for which the name Streptomyces osmaniensis sp. nov. is proposed.

\section{Description of Streptomyces osmaniensis sp. nov.}

Streptomyces osmaniensis (os.ma.ni.en'sis. N.L. masc. adj. osmaniensis pertaining to Osmania University, the source of the soil from which the type strain was isolated).

Aerobic, Gram-stain-positive, non-motile actinomycete that forms extensively branched substrate mycelium and aerial hyphae that differentiate into spiral chains of spinysurfaced spores. The aerial mycelium is grey and the substrate mycelium appears pale yellow on ISP medium 4 . Melanin pigments are formed on peptone-yeast extract iron agar (ISP medium 6) and tyrosine agar (ISP medium 7). Growth occurs at $15-40{ }^{\circ} \mathrm{C}$ and $\mathrm{pH}$ 6-10 but not at $45{ }^{\circ} \mathrm{C}$ or at $\mathrm{pH} 4$ or 11 . Growth occurs in the presence of $0.1 \%(\mathrm{w} / \mathrm{v})$ phenol and $4 \%(\mathrm{w} / \mathrm{v}) \mathrm{NaCl}$, but not in the presence of $7 \%(\mathrm{w} / \mathrm{v}) \mathrm{NaCl}$. Degrades starch, gelatin, xanthine, hypoxanthine, L-tyrosine, urea and Tween 80 , but not casein, DNA or xylan. Utilizes several compounds as sole carbon sources, including L-arabinose, cellobiose, cellulose $(0.1 \%)$, fructose, D-galactose, myo-inositol, lactose, maltose, D-mannitol, D-mannose, melibiose, raffinose, L-rhamnose, D-sorbitol, sucrose, xylose, acetate, pyruvate and succinate. Utilizes L-cysteine, L-histidine, L-isoleucine, L-phenylalanine and L-proline as sole nitrogen sources. Resistant to penicillin $\mathrm{G}\left(10 \mathrm{IU} \mathrm{ml}^{-1}\right)$, neomycin $(50 \mu \mathrm{g}$ $\mathrm{ml}^{-1}$ ) and rifampicin $\left(50 \mu \mathrm{g} \mathrm{ml} \mathrm{m}^{-1}\right)$, but sensitive to kanamycin $\left(30 \mu \mathrm{g} \mathrm{ml}^{-1}\right)$, novamycin $\left(30 \mu \mathrm{g} \mathrm{m}^{-1}\right)$ and streptomycin $\left(100 \mu \mathrm{g} \mathrm{ml}^{-1}\right)$. The predominant fatty acids are iso- $\mathrm{C}_{16: 0}$, iso- $\mathrm{C}_{15: 0}$, iso- $\mathrm{C}_{17: 0}$, anteiso- $\mathrm{C}_{15: 0}$, anteiso$\mathrm{C}_{17: 0}, \mathrm{C}_{16: 0}$ and iso- $\mathrm{C}_{14: 0}$. Shows antimicrobial activities against Escherichia coli MTCC 739, Bacillus subtilis MTCC 441, Staphylococcus aureus MTCC 96, Aspergillus niger MTCC 282 and Candida albicans MTCC 27.

The type strain, OU $-63^{\mathrm{T}}$ (=CCTCC AA209025 ${ }^{\mathrm{T}}=\mathrm{PCM}$ $2690^{\mathrm{T}}$ ), was isolated from a soil sample collected from Osmania University, Hyderabad, India.

\section{Acknowledgements}

We are grateful to Dr Paul Meyers, University of Cape Town (South Africa), and Dr Soon Dong Lee, Jeju National University (Republic of
Korea), for suggested changes to the manuscript and Mr Ravi Kumar (Indian Institute of Chemical Technology, Hyderabad) for his assistance with fatty acid and menaquinone analyses. T.V.K.R. thanks the University Grant Commission (UGC), Government of India, for provision of a fellowship grant.

\section{References}

Anderson, A. S. \& Wellington, E. M. H. (2001). The taxonomy of Streptomyces and related genera. Int J Syst Evol Microbiol 51, 797-814.

Atalan, E., Manfio, G. P., Ward, A. C., Kroppenstedt, R. M. \& Goodfellow, M. (2000). Biosystematic studies on novel streptomycetes from soil. Antonie van Leeuwenhoek 77, 337-353.

Berdy, J. (2005). Bioactive microbial metabolites. J Antibiot 58, 1-26. Chung, Y. R., Sung, K. C., Mo, H. K., Son, D. Y., Nam, J. S., Chun, J. S. \& Bae, K. S. (1999). Kitasatospora cheerisanensis sp. nov., a new species of the genus Kitasatospora that produces an antifungal agent. Int J Syst Bacteriol 49, 753-758.

Collins, M. D. (1985). Isoprenoid quinone analysis in classification and identification. In Chemical Methods in Bacterial Systematics, pp. 267-287. Edited by M. Goodfellow \& D. E. Minnikin. London: Academic Press.

Euzéby, J. P. (2009). List of Prokaryotic Names with Standing in Nomenclature. http://www.bacterio.cict.fr/

Felsenstein, J. (1985). Confidence limits on phylogenies: an approach using the bootstrap. Evolution 39, 783-791.

Fitch, W. M. (1971). Toward defining the course of evolution: minimum change for a specific tree topology. Syst Zool 20, 406-416.

Gonzalez, J. M. \& Saiz-Jimenez, C. (2005). A simple fluorimetric method for the estimation of DNA-DNA relatedness between closely related microorganisms by thermal denaturation temperatures. Extremophiles 9, 75-79.

Hasegawa, T., Takizawa, M. \& Tanida, S. (1983). A rapid analysis for chemical grouping of aerobic actinomycetes. J Gen Appl Microbiol 29, 319-322.

Jukes, T. H. \& Cantor, C. R. (1969). Evolution of protein molecules. In Mammalian Protein Metabolism, vol. 3, pp. 21-132. Edited by H. N. Munro. New York: Academic Press.

Kawato, M. \& Shinobu, R. (1959). On Streptomyces herbaricolor sp. nov., supplement: a single technique for microscopical observation. Mem Osaka Unit Lib Arts Educ B Nat Sci 8, 114-119.

Kim, S. B. \& Goodfellow, M. (2002). Streptomyces avemitilis sp. nov., nom. rev., a taxonomic home for the avermectin-producing streptomycetes. Int J Syst Evol Microbiol 52, 1225-1228.

Kim, S. B., Lonsdale, J., Seong, C. N. \& Goodfellow, M. (2003). Streptacidiphilus gen. nov., acidophilic actinomycetes with wall chemotype I and emendation of the family Streptomycetaceae (Waksman \& Henrici $1943^{\mathrm{AL}}$ ) emend. Rainey et al. (1997). Antonie van Leeuwenhoek 83, 107-116.

Kumar, S., Tamura, K., Jakobsen, I. B. \& Nei, M. (2001). MEGA2: Molecular Evolutionary Genetics Analysis software. Tempe, AZ: Arizona State University.

Lane, D. J. (1991). 16S/23S rRNA sequencing. In Nucleic Acid Techniques in Bacterial Systematics, pp. 115-175. Edited by E. Stackebrandt \& M. Goodfellow. Chichester: Wiley.

Lechevalier, M. P. \& Lechevalier, H. A. (1970). Chemical composition as a criterion in the classification of aerobic actinomycetes. Int J Syst Bacteriol 20, 435-443.

Lechevalier, M. P. \& Lechevalier, H. A. (1980). The chemotaxonomy of actinomycetes. In Actinomycete Taxonomy, pp. 227-291. Edited by 
A. Dietz \& D. W. Thayer. Arlington, VA: Society for Industrial Microbiology.

Lepage, G. \& Roy, C. C. (1984). Improved recovery of fatty acid through direct transesterification without prior extraction or purification. J Lipid Res 25, 1391-1396.

Mandel, M. \& Marmur, J. (1968). Use of ultraviolet absorbancetemperature profile for determining the guanine plus cytosine content of DNA. Methods Enzymol 12B, 195-206.

Manfio, G. P., Zakrzewska-Czerwinska, J., Atalan, E. \& Goodfellow, M. (1995). Towards minimal standards for the description of Streptomyces species. Biotechnologiia 8, 228-237.

Manfio, G. P., Atalan, E., Zakrzewska-Czerwinska, J., Mordarski, M., Rodríguez, C., Collins, M. D. \& Goodfellow, M. (2003). Classification of novel soil streptomycetes as Streptomyces aureus sp. nov., Streptomyces laceyi sp. nov. and Streptomyces sanglieri sp. nov. Antonie van Leeuwenhoek 83, 245-255.

Olson, E. H. (1968). Actinomycetes Isolation Agar. Supplementary Literature. Detroit, MI: Difco Laboratories.

Rosselló-Mora, R. \& Amann, R. (2001). The species concept for prokaryotes. FEMS Microbiol Rev 25, 39-67.

Saitou, N. \& Nei, M. (1987). The neighbor-joining method: a new method for reconstructing phylogenetic trees. Mol Biol Evol 4, 406425.

Sembiring, L., Ward, A. C. \& Goodfellow, M. (2000). Selective isolation and characterisation of members of the Streptomyces violaceusniger clade associated with roots of Paraserianthes falcataria. Antonie van Leeuwenhoek 78, 353-366.

Shirling, E. B. \& Gottlieb, D. (1966). Methods for characterization of Streptomyces species. Int J Syst Bacteriol 16, 313-340.
Shirling, E. B. \& Gottlieb, D. (1968). Cooperative description of type cultures of Streptomyces. II. Species descriptions from first study. Int $J$ Syst Bacteriol 18, 69-189.

Shirling, E. B. \& Gottlieb, D. (1972). Cooperative description of type cultures of Streptomyces. V. Additional descriptions. Int J Syst Bacteriol 22, 265-394.

Tripathi, G. \& Rawal, S. K. (1998). A simple and efficient protocol for isolation of high molecular weight DNA from Streptomyces aureofaciens. Biotechnol Tech 12, 629-631.

Waksman, S. A. \& Henrici, A. T. (1943). The nomenclature and classification of the actinomycetes. J Bacteriol 46, 337-341.

Wayne, L. G., Brenner, D. J., Colwell, R. R., Grimont, P. A. D., Kandler, O., Krichevsky, M. I., Moore, L. H., Moore, W. E. C., Murray, R. G. E. \& other authors (1987). International Committee on Systematic Bacteriology. Report of the ad hoc committee on reconciliation of approaches to bacterial systematics. Int J Syst Bacteriol 37, 463-464.

Williams, S. T. \& Davies, F. L. (1967). Use of scanning electron microscope for the examination of actinomycetes. J Gen Microbiol 48, 171-177.

Williams, S. T., Goodfellow, M., Alderson, G., Wellington, E. M. H., Sneath, P. H. A. \& Sackin, M. J. (1983). Numerical classification of Streptomyces and related genera. J Gen Microbiol 129, 1743-1813.

Williams, S. T., Goodfellow, M. \& Alderson, G. (1989). Genus Streptomyces Waksman and Henrici 1943, 339 ${ }^{\mathrm{AL}}$. In Bergey's Manual of Systematic Bacteriology, vol. 4, pp. 2452-2492. Edited by S. T. Williams, M. E. Sharpe \& J. G. Holt. Baltimore: Williams \& Wilkins.

Zhou, Z. H., Liu, Z. H., Qiao, Y. D., Kim, S. B. \& Goodfellow, M. (1998). Saccharopolyspora spinosporotrichia sp. nov., a novel actinomycete from soil. Int J Syst Bacteriol 48, 53-58. 